\title{
Modulated Electrohyperthermia: A New Hope for Cancer Patients
}

\author{
Huda F. Alshaibi $\mathbb{D}^{1}{ }^{1}$ Bashayr Al-shehri, ${ }^{2}$ Basmah Hassan $\mathbb{D}^{2}$ Raghad Al-zahrani $\mathbb{D}^{2}{ }^{2}$ \\ and Taghreed Assiss $\mathbb{D}^{2}$ \\ ${ }^{1}$ Faculty of Science Biochemistry Department, King Abdulaziz University, Saudi Arabia P.O. Box 52502, Jeddah 21573 \\ ${ }^{2}$ Faculty of Science Biochemistry Department, Undergraduate Students at King Abdulaziz University, Saudi Arabia
}

Correspondence should be addressed to Huda F. Alshaibi; halshaibi@kau.edu.sa

Received 7 September 2020; Revised 14 October 2020; Accepted 31 October 2020; Published 16 November 2020

Academic Editor: Ming Yi

Copyright (c) 2020 Huda F. Alshaibi et al. This is an open access article distributed under the Creative Commons Attribution License, which permits unrestricted use, distribution, and reproduction in any medium, provided the original work is properly cited.

\begin{abstract}
According to the World Health Organization, the prevalence of cancer has increased worldwide. Oncological hyperthermia is a group of methods that overheat the malignant tissues locally or systematically. Nevertheless, hyperthermia is not widely accepted, primarily because of the lack of selectivity for cancer cells and because the temperature-triggered higher blood flow increases the nutrient supply to the tumor, raising the risk of metastases. These problems with classical hyperthermia led to the development of modulated electrohyperthermia (mEHT). The biophysical differences of the cancer cells and their healthy hosts allow for selective energy absorption on the membrane rafts of the plasma membrane of the tumor cells, triggering immunogenic cell death. Currently, this method is used in only 34 countries. The effectiveness of conventional oncotherapies increases when it is applied in combination with mEHT. In silico, in vitro, and in vivo preclinical research studies have all shown the extraordinary ability of mEHT to kill malignant cells. Clinical applications have improved the quality of life and the survival of patients. For these reasons, many other research studies are presently in progress worldwide. Thus, the objective of this review is to highlight the capabilities and advantages of mEHT and provide new hopes for cancer patients worldwide.
\end{abstract}

\section{Introduction}

Cancer is the second leading cause of death worldwide and is considered a universal public health problem with a large impact on healthcare costs. According to the World Health Organization [1], cancer was responsible for around 9.6 million deaths globally in 2018 (WHO 2018).

Ever since cancer was discovered, researchers have struggled to find the best treatment for this lethal disease. As a result, many types of treatments have been developed, including surgery, chemotherapy, radiotherapy, and, more recently, immunotherapy. Among these modalities, the correct choice for patients varies depending on the type and stage of their disease.

One method known to ancient medical practitioners was oncological hyperthermia. This method was described as the overheating of malignant tissues, either locally or systematically. It was the first known oncological therapy used by Hippocrates [2]. In modern times, this technique was used in
1898 by the Swedish gynaecologist Westermark. Westermark treated cervical cancer by running hot water through an intracavitary spiral tube. He noticed an excellent clinical response. Unfortunately, exposing normal healthy tissue to a high temperature for a long time had unfavourable effects [3], in addition to lacking selectivity and thereby damaging the healthy surrounding tissue. Overheating causes increased blood flow, which increases the delivery of nutrients to cancer cells. Moreover, increased blood flow helps disseminate cancer cells and increases the risk of metastasis [4]. The desire to eliminate these side effects of classical hyperthermia led to the discovery of the electromagnetic heating method. This new paradigm is possible due to modulated electrohyperthermia (mEHT), which makes cellular selection possible [5]. The heterogeneous absorption of energy caused by this technique follows the natural biophysical heterogeneity of the tumor and its surrounding tissue [6]. Consequently, the selectively tuned technique changes the isothermal (homogeneous) heating procedures in conventional hyperthermia. 
This technique is used in five continents and 34 countries, with approximately 400,000 treatments performed each year [6]. However, it is not yet known/used in many other countries.

1.1. mEHT Mode of Action. The mEHT technique is based on two principles: (1) it replaces the single temperature concept that was used previously in hyperthermia with energy that is measured in $(\mathrm{kJ} / \mathrm{kg})$, returning the technique to the gold standard dose concepts known to radiation oncologists [4]; (2) it selectively delivers this energy into the tumor without affecting the healthy neighbouring tissue $[7,8]$. To successfully target tumor cells, the modified metabolic and biophysical conditions of cancer cells allow for selective targeting of the energy [9]. In contrast to normal cells, cancer cells rely mainly on anaerobic glycolysis, regardless of oxygen availability. This phenomenon is known as the "Warburg effect" [10]. The fermentation of glucose by cancer cells results in the production of two ATP molecules rather than the 36 ATP molecules that result from the complete oxidation of glucose in the mitochondria of healthy cells [11]. Many applications take advantage of this fundamental difference, such as positron emission tomography (PET) diagnosis. As a result of the increased glucose uptake, the lactic acid production increases, and other metabolites contribute to a higher proliferation rate in the microenvironment of the cancer cells. The subsequently decreased extracellular $\mathrm{pH}$ and "reversed" intracellular $\mathrm{pH}$ [12-14] also help identify the cancer cells.

The basic metabolic differences between cancer and noncancer cells make their electrical recognition possible [15] and include the following characteristics:

(A) The ability of cancer cells to produce sufficient ATP is low. A large amount of ATP is needed for proliferative energy consumption. Cancer has less ATP for active membrane stabilization by $\mathrm{K}^{+}$and $\mathrm{Na}^{+}$transport; thus, the membrane potentiation weakens [16]

(B) The cellular membrane of cancerous cells is electrochemically different from normal cells, since they are negatively charged on average $[17,18]$

(C) The composition of membrane lipids and sterols differs dramatically between cancer cells and normal healthy cells [19-21]

As a result of these differences, the membrane permeability of cancer cells is altered. Thus, the efflux of $\mathrm{K}^{+}, \mathrm{Mg}_{2}{ }^{+}$, and $\mathrm{Ca}_{2}{ }^{+}$ions increases, whereas the efflux of $\mathrm{Na}^{+}$and water transport from the cell decreases. Accordingly, the cell swells, which causes an additional reduction in its membrane potential. Furthermore, as the network of cellular connections (cadherins and junctions) [5] are broken, the cancer cells become autonomic, changing the dielectric properties (growing the dielectric permeability) of the microenvironment [15], while the resistance decreases. All of these factors contribute to the negative polarization of the tumor and an increase in its conductivity, which is used in electrochemical cancer therapy $[22,23]$.
1.2. The Working Principle of $m E H T$. Using $m E H T$ requires a very simple methodological setup [24] that depends on nonequally heating the target area and concentrating the absorbed energy into the extracellular electrolytes [25]. This technique creates nonhomogeneous heating by increasing the temperature gradient between the intracellular and extracellular liquids. The resulting heterogeneity leads to a change in membrane processes and uses the strong synergy between the electrical and temperature effects [26] to initiate the signalling pathway responsible for apoptosis instead of necrosis [9]. This method also uses a modulated radiofrequency current, which flows through the cancerous lesion where it is automatically focused by the higher current density [6] due to its lower resistance [27]. The cancer cell membranes are electrically isolated by more than one million $\mathrm{V} / \mathrm{m}$ field strength, directing the current flow mainly into the extracellular electrolytes [28-30]. Together, the conductivity and permeability differences can precisely distinguish the cancer cells from healthy cells [26, 31-34]. One of the expected results is membrane disruption of the electrically selected cells. The action of the electric field on cellular division has been extensively studied by various research groups [3537]. In contrast to what is observed in simple heating processes, the physiological feedback mechanisms of homeostasis do not limit the effects of the electric field, and the adverse effects caused by the increased blood supply can be reduced. The mEHT process primarily delivers energy into the extracellular liquid, which heats up and creates a slight $\left(1 / 1000^{\circ} \mathrm{C}\right)$ temperature difference between the inner and outer temperatures of the cell. Although this difference appears minor, considering how tiny the membrane layer is ( $5 \mathrm{~nm}$ ), the difference in standard conditions is so high that it may reach $\sim 200,000^{\circ} \mathrm{C} / \mathrm{m}[38]$.

Among the numerous advantages of using mEHT, the main one is the localisation of the high thermal load to only a narrow and precise region of the plasma membrane of the malignant cell [39], where the lipid rafts, which are in the nanoscopic range, can absorb the major energy load [40]. As studies have shown, the size of these rafts depends on the host cells: 10 to $-100 \mathrm{~nm}$ [41], 25 to $-700 \mathrm{~nm}$ [42], or 100 to $-200 \mathrm{~nm}$ [43]. This nanoscopic focus is similar to radiotherapy, where the main target is the breaks of the DNA strand in radiotherapy and the lipid rafts in mEHT [44]. The size and selection similarity is shown in Figure 1 [45].

Due to the proper selection and the individual adaptation of the treatment, mEHT is highly personalised [46]. Consequently, cellular destruction of the malignancy does not require a high-temperature isothermal spot. This fact has physiological advantages and reduces the adverse effects and hot spots. In conventional hyperthermia, the overheating of the healthy tissues causes a massive number of complaints during the treatment process [47]. In mEHT, the local thermal and nonthermal effects [6] are completed with modulation-induced synchrony [48], and the nonsynchronous pathological patterns are recognised [49], opening up the technique to theranostic possibilities [50]. The nonequilibrium heating does not affect the membrane rafts, but the absorbed energy heats the extracellular electrolyte differently than other electrolyte compartments of the selected 


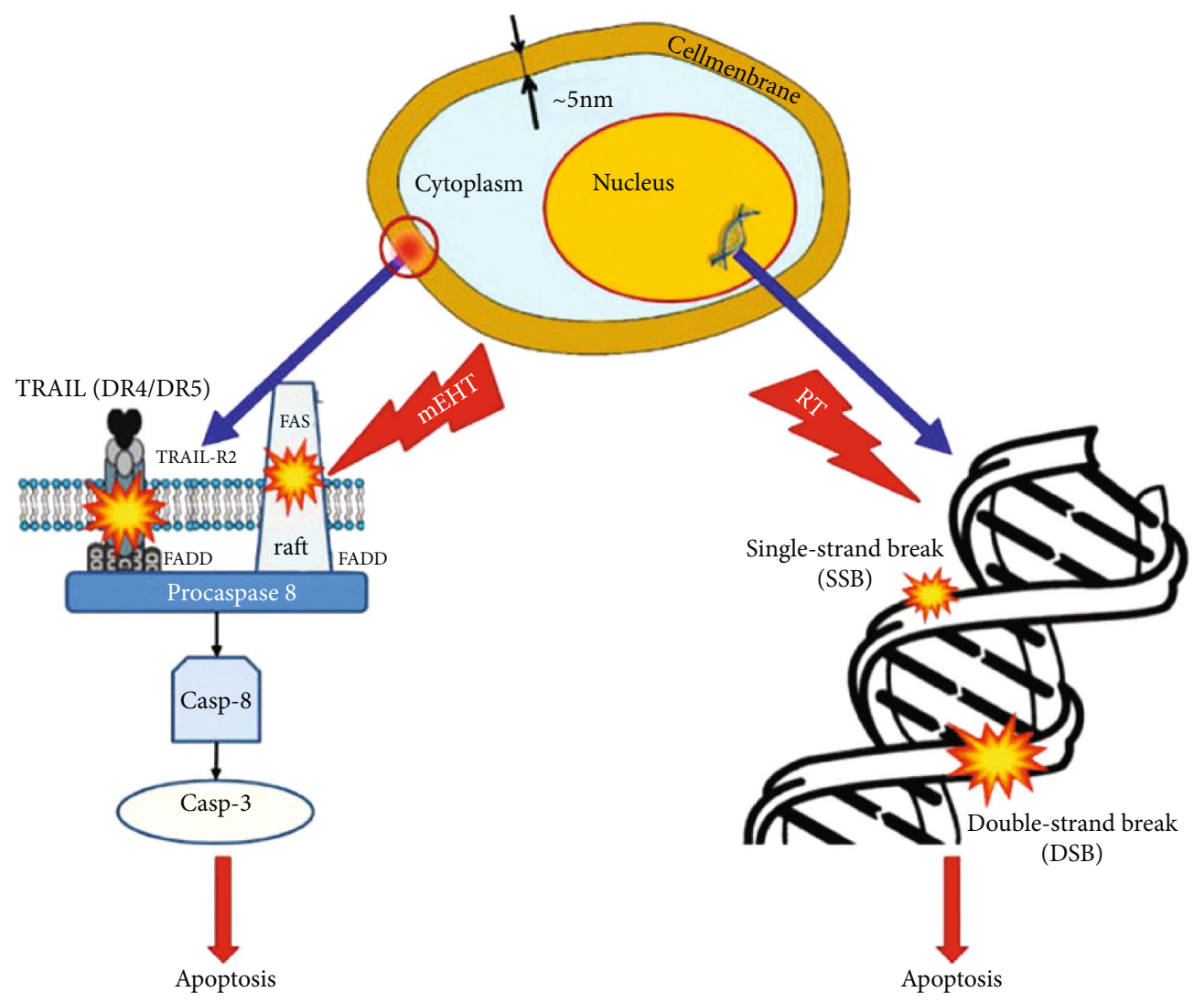

FIGURE 1: Principle of mEHT therapy. The principles of mEHT and radiotherapy are similar, targeting nano range-sized parts of the cells to induce destruction this figure was adapted from Szasz A [45].

malignant cells, creating a heat flow through the membrane into the cytosol. Thus, the heat flow will remain active until an equilibrium is reached, as depicted in Figure 2. This process explains the efficacy and reliability of the treatment [4].

In prior studies, phantom measurements of the thermal effects caused by increased temperatures were taken in chopped meat and the liver of a pig [51]. Importantly, an appropriately elevated temperature was measured in the liver of the anesthetised living pig [52]. A thermal effect appropriate for complementary preclinical applications of chemotherapy [53] and radiotherapy [54] was measured. A clinical trial has also shown an appropriate temperature increase for radiochemotherapy without risk of adverse effects in a human uterus cervix [55], which was an important observation of the enhanced pharmacokinetic processes [56].

1.3. In Vitro Studies Using mEHT. Many researchers have investigated the effects of $\mathrm{mEHT}$ on various in vitro cell cultures and in vivo allografts and xenografts. Comparisons have shown significant differences between cells treated with the same temperature through mEHT and conventional hyperthermia $[9,57]$, even in comparison to other capacitive techniques [58]. These studies highlight the differences between cancer cells and normal cells and the advantage of being able to destroy cancer cells selectively. A remarkable number of in vitro and preclinical studies revealed that mEHT induces apoptosis rather than necrosis that characteristically results from traditional hyperthermia after an equiv- alent dose and cumulative time at $43^{\circ} \mathrm{C}$ [59]. This apoptotic process was shown using various methods, including morphology, p53 expression, TUNEL assays, and DNA fragmentation [4]. Various in vitro cell culture studies and in vivo allograft and xenograft studies have also observed and documented the synergy of the electric field (nonthermal effect) and the heat (thermal effects) in the mEHT cell destruction mechanism [26, 60]. Another study by Meggyeshazi et al. (2014) treated a HT29 colorectal cancer xenograft with a single shot of mEHT for $30 \mathrm{~min}$ at an average power of $4 \mathrm{~W}$ and made comparisons with an untreated group. The results showed a vigorous destruction of the invasive colorectal cancer xenograft with a seven-fold peak at $72 \mathrm{~h}$ in the group treated with mEHT compared to the untreated control group. The mEHT treatment also caused a significant elevation of DNA fragmentation, nuclear shrinkage, and an increased number of apoptotic bodies. Furthermore, it caused an increase in both the amount of BAX protein and the release of cytochrome $\mathrm{c}$ from the mitochondria to the cytoplasm, indicating that $\mathrm{mEHT}$ caused the tumor to undergo apoptosis by activating the caspase-independent apoptosis [61] and caspase-dependent [58] pathways.

The mechanism by which mEHT produces apoptosis is important, leading to damage-associated molecular pattern (DAMP) signals that cause immunogenic tumor cell death (ICD). DAMP signals can stimulate the uptake of tumor antigens by antigen-presenting cells [62]. The process of DAMP signals leading to ICD is well known and explained in other 

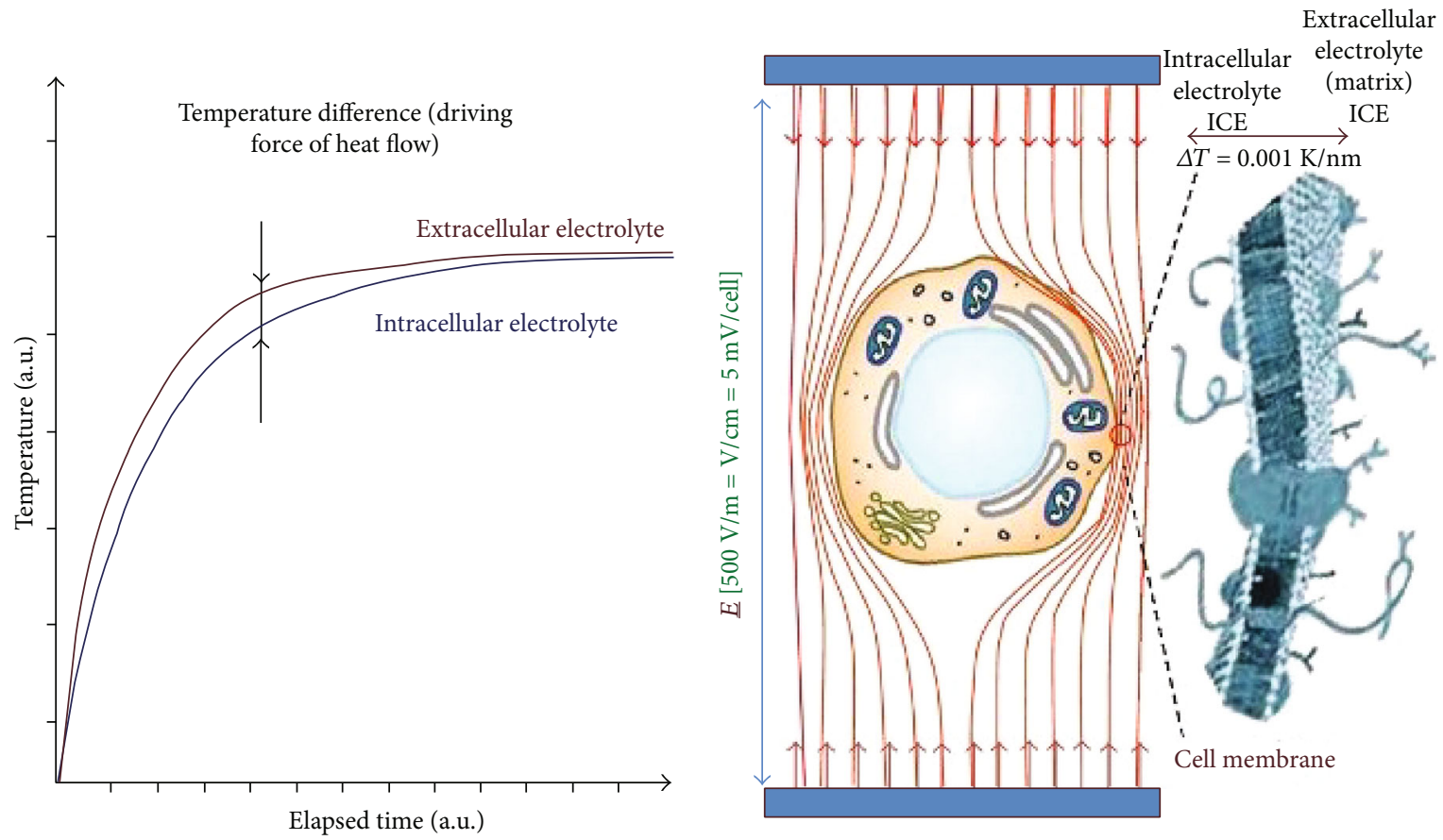

Figure 2: Oncothermia targeting the extracellular electrolytes. Oncothermia delivers its energy mainly into extracellular electrolytes, creating a temperature gradient through the cellular membrane [4]. The thermal gradient action due to nonhomogeneous heating is active, until the thermal equilibrium equalises the temperature; this figure was adapted from Gabriella et al. [4].

cancer treatments, such as chemotherapy [63]. The ICD mechanism involves the translocation of calreticulin to the preapoptotic cell membrane, where heat shock proteins (Hsp70 and Hsp90) and the release of ATP can be observed at the early stages of apoptosis. This process is followed by the passive release of high-mobility group box 1 (HMGB1) at the late stages [64-68], as shown in Figure 3. Thus, the combination of DAMP signals and cancer antigens can facilitate the maturation of antigen-presenting cells and activate antitumor T-cell immunity $[68,69]$. Another mEHT study induced the transcription of Hsp70 and Hsp90 together with other members of the heat shock protein family in a xenograft model by subcutaneously injecting colorectal HT29 cancer cells into the femoral region of Balb/c (nu/nu) mice [62]. Furthermore, an early accumulation of calreticulin on the cell membrane was detected after treatment with mEHT [62]. These findings support the rationale of using $\mathrm{mEHT}$ as a supplementary therapy with other cancer therapies, such as chemotherapy and radiation. This finding was also supported by another study by Qin et al. (2014) that investigated the benefits of combining mEHT with dendritic cell (DC) immunotherapy on a squamous cell carcinoma (SCCVII) cancer model. This study found that treating the tumors on the legs of mice with mEHT together with injecting DCs resulted in a significant inhibition of the growth of distant tumors on the chest [70]. The same results were obtained in another study [71] when the researchers detected a vaccinelike behaviour in the mEHT process. After the abscopal processes, rechallenging the same tumor in the animal was unsuccessful. This phenomenon is known as the "abscopal effect," in which irradiating localised tumors cause shrinking in the target tumors and tumors located far from the irradiated area.
Although the mechanism underlying the abscopal effect is unclear, the results of the study conducted by Qin et al. in 2014 suggest that it may depend on the activation of the immune system, which is mediated by $\mathrm{T}$ cells via the $\mathrm{CD}^{+}$ and $\mathrm{CD} 8^{+}$that were activated in the group treated with both mEHT and DC immunotherapy. Moreover, this group showed a high level of expression of a different heat shock protein (GP96), which plays an important role in the uptake of antigens by DCs [70].

A systemic tumor-specific immunological response could be a key in successfully treating cancer patients. The tumor microenvironment (TME) triggers the immunological response [72]. The penetrating DC could be matured in the TME or in the lymph nodes and form an antigenpresenting cell (APC). The APC creates $\mathrm{CD}^{+}$, killing T cells prepared for the immune responses [73]. This concept of combining DC-based cancer immunotherapy with radiotherapy was used before to treat cancer patients without particular success [74]. The reasons for this failure are not clear, but it is likely that a satisfactory number of DCs were not available; consequently, the maturation of DC did not produce enough APCs for the $\mathrm{CD}^{+}$. Another explanation may be that the available DCs differentiated into immunosuppressive regulatory forms due to the poor TME and inhibited the activation of T cells, missing a characteristic to block the cancer progression [75]. The search for a solution to this challenge led to adding heat shock proteins and electrogene therapy to improve the efficacy of DC immunotherapy [76]. Although it is not yet clear how to manipulate this therapy to achieve an optimal induction of antitumor immunity, ICD appears to be the main factor in a favourable immunogenic TME [74, 77-80]. 


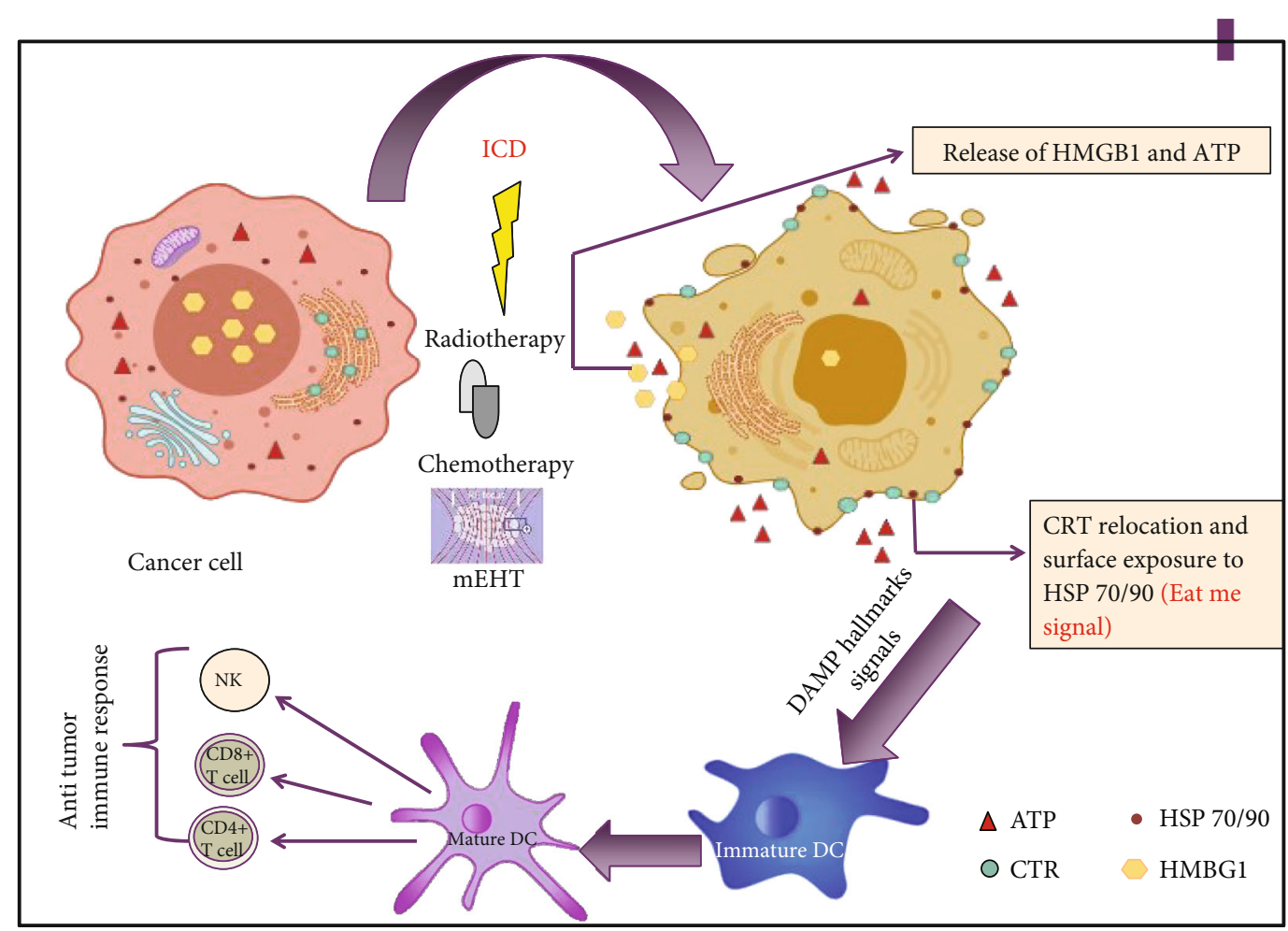

FIgURE 3: Schematic representation of the stimulation of immunogenic cell death- (ICD-) treating cells with different ICD inducers, such as chemotherapy, radiotherapy, and mEHT, results in the induction of cancer cells, which leads them to undergo apoptosis. Subsequently, apoptotic cells express damage-associated molecular pattern (DAMP) hallmarks, including the translocation of calreticulin from the endoplasmic reticulum to the cell surface, the release of high-mobility group B1 (HMGB1) from the nucleus, the extracellular secretion of ATP, and the expression of various heat shock proteins on the cell surface. This DAMP signal leads to the activation and maturation of dendritic cells, followed by activating several antitumor immune responses. This figure was adapted from Zhou et al. [124].

A study by Qin et al. that used both DC immunotherapy and $\mathrm{mEHT}$ interested the researchers in studying $\mathrm{mEHT}$ and its abscopal effect in experimental in vivo models. In addition to the help its ICD production provides in forming APC, another advantage of $\mathrm{mEHT}$ is its tumor-selective focus, which does not affect the available immune cells. As a result, they remain intact for the expected immune actions. In one study, a CT26 murine colorectal cancer allograft model was used in a combined DC and mEHT therapy [71]. The researchers found that mEHT significantly induced apoptosis and increased the release of Hsp70 into the extracellular matrix, transporting out genetic information. Moreover, a combined treatment of mEHT and DC immunotherapy significantly inhibited the growth of the tumor and increased the number of leukocytes and macrophages, causing more immune effects. This study concluded that mEHT could produce a positive TME for an immunological chain reaction, improving the success rate of intratumoral DC immunotherapy [71]. The findings of this study were similar and confirmed later in a study by Vancsik et al. (2018), which used the same CT26 murine colorectal cancer allograft model and concluded that mEHT induced apoptosis through the stimulation of caspase-dependent programmed cell death and through the release of stress-associated DAMP proteins. Tumor-specific killer $\mathrm{T}$ cells subsequently activated, and tumor destruction continued through the immunogenic cell death mechanism, causing the abscopal effect that was sug- gested in previous studies [81]. Moreover, the in vitro experiments that studied the abscopal effect of mEHT in vivo studies was also conducted such as the study done by Minnaar which involved phase III randomized human trial of cervical cancer the results of this study support the in vitro results earlier and provided evidence of an abscopal effect associated with adding $\mathrm{mEHT}$ to the treatment protocol of these patients [82].

Another study investigated the molecular mechanism underlying the cytotoxic effects of mEHT on different cell types of hepatocellular carcinoma (Huh7 and HepG2) and found that treating hepatocellular carcinoma cells with mEHT increased the inhibitory effect due to a subset of molecular changes. The molecular changes included the upregulation of septin 4 (SEPT4) and inhibition of Gprotein-coupled receptor 64 (GPR64), a key regulator of invasiveness, accompanied by the renewal of cyclindependent kinase inhibitor p21. These changes enhanced the apoptotic signalling caused by mEHT. In addition, mEHT inhibited the growth of hepatocellular carcinoma xenograft in nude mice [83].

1.4. Clinical Trials Using $m E H T$ in Combination with Other Cancer Therapies. Recently, a comprehensive review was published showing the clinical achievements of mEHT that were mirrored in numerous publications [84]. Many preclinical investigations were successfully followed by clinical trials, 
TABLE 1: Clinical trials that used mEHT in combination with other treatments.

\begin{tabular}{|c|c|c|c|c|c|}
\hline No. & Tumor site & $\begin{array}{l}\text { Number of } \\
\text { patients }\end{array}$ & Treatment used & Results & Reference \\
\hline 1 & $\begin{array}{l}\text { Relapsed high-grade } \\
\text { gliomas }\end{array}$ & 15 & mEHT + alkylating chemotherapy & $\begin{array}{l}\text { Tolerable and safe for patients with relapses } \\
\text { even with a high escalation of the dose. }\end{array}$ & {$[96]$} \\
\hline 2 & Advanced gliomas & 12 & $\begin{array}{l}\text { Chemotherapy }+ \text { radiotherapy }+ \\
\text { mEHT }\end{array}$ & $\begin{aligned} \mathrm{CR}=1, \mathrm{PR} & =2, \mathrm{RR}=25 \% . \text { Median duration of } \\
\text { response }= & 10 \mathrm{~m} . \text { Median survival }=9 \mathrm{~m}, 25 \% \\
& \text { survival rate at } 1 \text { year. }\end{aligned}$ & [97] \\
\hline 3 & $\begin{array}{l}\text { Relapsed malignant } \\
\text { gliomas }\end{array}$ & 24 & mEHT & $\begin{array}{c}\text { Median survival }=19.5 \mathrm{~m}, 55 \% \text { survival rate at } 1 \\
\text { year, } 15 \% \text { at } 2 \text { years. }\end{array}$ & {$[98]$} \\
\hline 4 & $\begin{array}{l}\text { Advanced } \\
\text { glioblastoma }\end{array}$ & 60 & mEHT + immunotherapy & $\begin{array}{l}\text { No added toxicity by immunotherapy. Median } \\
\text { progression-free survival (PFS) }=13 \mathrm{~m} \text {. Median } \\
\text { follow-up } 17 \mathrm{~m} \text {, median OS was not reached. } \\
\text { Estimated OS at } 30 \mathrm{~m} \text { was } 58 \% \text {. }\end{array}$ & {$[87]$} \\
\hline 5 & $\begin{array}{l}\text { Various brain- } \\
\text { gliomas }\end{array}$ & 140 & $\begin{array}{c}\text { Chemotherapy }+ \text { radiotherapy }+ \\
\text { mEHT }\end{array}$ & OS $=20.4 \mathrm{~m} . \mathrm{mEHT}$ was safe and well tolerated. & [99] \\
\hline 6 & High-grade gliomas & 179 & $\begin{array}{l}\text { mEHT + radiotherapy }+ \\
\text { chemotherapy }\end{array}$ & $\begin{array}{l}\text { Longstanding complete and partial remissions } \\
\text { after recurrence in both groups. }\end{array}$ & {$[100]$} \\
\hline 7 & $\begin{array}{l}\text { Glioblastoma \& } \\
\text { astrocytoma }\end{array}$ & 149 & $\begin{array}{c}\text { mEHT }+ \text { radiotherapy }+ \\
\text { chemotherapy (BSC, palliative } \\
\text { range) }\end{array}$ & $\begin{array}{l}5 \mathrm{y}-\mathrm{OS}=83 \%(\mathrm{AST}) \text { in } \mathrm{mEHT} \text { vs. } 5 \mathrm{y}-\mathrm{OS}=25 \% \\
\text { by BSC. } 5 \mathrm{y}-\mathrm{OS}=3.5 \% \text { in } \mathrm{mEHT} \text { vs. } 5 \mathrm{y}- \\
\mathrm{OS}=1.2 \% \text { by BSC for GBM. Median OS }=14 \mathrm{~m} \\
\text { of } \mathrm{mEHT} \text { for GBM and OS }=16.5 \mathrm{~m} \text { for AST. }\end{array}$ & {$[101]$} \\
\hline 8 & $\begin{array}{l}\text { Advanced } \\
\text { hepatocell. } \\
\text { carcinoma }\end{array}$ & 21 & Chemotherapy + mEHT & $\begin{array}{c}\mathrm{PR}=1, \mathrm{CR}=0, \mathrm{SD}=11 . \text { Combined therapy was } \\
\text { effective, and no major complications were } \\
\text { observed. }\end{array}$ & {$[102]$} \\
\hline 9 & $\begin{array}{l}\text { Refractory } \\
\text { hepatocell. } \\
\text { carcinoma }\end{array}$ & 22 & $\begin{array}{l}\text { mEHT + thermo-active agents } \\
\text { (TAA) or mEHT without TAA }\end{array}$ & $\begin{array}{c}\mathrm{CR}=1, \mathrm{PR}=0 . \text { Median } \mathrm{OS}=20.5 \text { weeks. } 50 \% \\
\text { showed evidence of increasing QoL and } \\
\text { minimal toxicity. }\end{array}$ & {$[103]$} \\
\hline 10 & $\begin{array}{l}\text { Small-cell lung } \\
\text { cancer (SCLC) }\end{array}$ & 22 & Chemotherapy + mEHT & $\begin{array}{l}\text { mEHT-enhanced destruction of the cancer } \\
\text { cells. Improved the OS of patients, too. }\end{array}$ & {$[104]$} \\
\hline 11 & $\begin{array}{l}\text { Advanced cervical } \\
\text { cancer }\end{array}$ & 236 & $\begin{array}{l}\text { Random. Phase III } \\
\text { chemoradiation alone CHR and } \\
\text { mEHT group (mEHT + CHR) } \\
\text { [preliminary data] }\end{array}$ & $\begin{array}{l}\text { Preliminary data for the first } 100 \text { participants. } \\
\text { A positive trend in survival and local disease } \\
\text { control by mEHT. No significant differences in } \\
\text { acute adverse events or QoL between the } \\
\text { groups. }\end{array}$ & {$[105]$} \\
\hline 12 & $\begin{array}{l}\text { Advanced cervical } \\
\text { cancer }\end{array}$ & 38 & Chemotherapy \pm mEHT & $\begin{array}{c}\text { The overall response }(\mathrm{CR}+\mathrm{PR}+\mathrm{SD} \text { vs. } \mathrm{PD}) \\
\text { was significantly greater with mEHT. No } \\
\text { complications or extra adverse effects by } \\
\text { mEHT. }\end{array}$ & {$[106]$} \\
\hline 13 & $\begin{array}{l}\text { Advanced cervical } \\
\text { cancer }\end{array}$ & 72 & $\begin{array}{c}\text { Radiotherapy }+ \text { chemotherapy }+ \\
\text { mEHT }\end{array}$ & $\begin{array}{c}\mathrm{CR}+\mathrm{PR}=73.5 \%, \mathrm{SD}=14.7 \% . \text { The addition of } \\
\text { mEHT increased the QoL and OS. }\end{array}$ & [107] \\
\hline 14 & $\begin{array}{l}\text { Advanced cervical } \\
\text { carcinoma }\end{array}$ & 20 & $\begin{array}{l}\text { mEHT + radiotherapy + } \\
\text { chemotherapy }\end{array}$ & $\begin{array}{l}\text { mEHT increased the peritumor temperature } \\
\text { and blood flow in human cervical tumors, } \\
\text { promoting the radiotherapy }+ \text { chemotherapy. }\end{array}$ & [55] \\
\hline 15 & $\begin{array}{l}\text { Advanced cervical } \\
\text { carcinoma }\end{array}$ & 108 & mEHT + chemoradiotherapy & $\begin{array}{c}\text { The complete metabolic response (CMR) of } \\
\text { disease outside the radiation field at } 6 \mathrm{~m} \\
\text { posttreatment shows the abscopal effect, } \\
\text { significantly associated with the addition of } \\
\text { mEHT. }\end{array}$ & {$[82]$} \\
\hline 16 & $\begin{array}{l}\text { Advanced cervical } \\
\text { carcinoma }\end{array}$ & 206 & $\begin{array}{l}\text { Random. Phase III } \\
\text { chemoradiation alone }[108] \text { and } \\
\text { mEHT group (mEHT }+\mathrm{CHR}) \\
\text { [preliminary data] }\end{array}$ & $\begin{array}{l}\text { Compliance to mEHT treatment was high ( } 97 \% \\
\text { completed } \geq 8 \text { treatments) with no significant } \\
\text { differences in CRT-related toxicity between } \\
\text { treatment groups or between HIV-positive and } \\
\text { HIV-negative participants. }\end{array}$ & {$[86]$} \\
\hline 17 & $\begin{array}{l}\text { Advanced cervical } \\
\text { carcinoma }\end{array}$ & 202 & mEHT + chemoradiotherapy & $\begin{array}{l}\text { Six-month local disease-free survival } \\
(\mathrm{LDFS})=38.6 \% \text { for } \mathrm{mEHT} \text { and } \mathrm{LDFS}=19.8 \% \\
\text { without } \mathrm{mEHT}(\boldsymbol{p}=\mathbf{0 . 0 0 3}) . \text { Local disease }\end{array}$ & {$[85]$} \\
\hline
\end{tabular}


TABle 1: Continued.

\begin{tabular}{|c|c|c|c|c|c|}
\hline No. & Tumor site & $\begin{array}{l}\text { Number of } \\
\text { patients }\end{array}$ & Treatment used & Results & Reference \\
\hline 18 & Stage III-IV NSCLC & 15 & $\begin{array}{c}\text { Ascorbic acid (AA) infusion }+ \\
\text { mEHT }\end{array}$ & $\begin{array}{l}\text { control }(\mathrm{LDC})=45.5 \% \text { with } \mathrm{mEHT} \\
\text { LDC }=24.1 \% \text { without } \mathrm{mEHT} ;(\boldsymbol{p}=\mathbf{0 . 0 0 3}) \\
\text { AA safely synergises with mEHT and was well } \\
\text { tolerated with no major adverse effects. }\end{array}$ & [109] \\
\hline 19 & Advanced NSCLC & 97 & $\begin{array}{l}\text { mEHT + radiotherapy + } \\
\quad \text { chemotherapy }\end{array}$ & $\begin{array}{c}\text { Median OS }=9.4 \mathrm{~m} \text { with } \mathrm{mEHT} \text { OS }=5.6 \mathrm{~m} \\
\text { without } \mathrm{mEHT} ;(\boldsymbol{p}<\mathbf{0 . 0 0 0 1}) . \text { Median } \\
\text { PFS }=3 \mathrm{~m} \text { for } \mathrm{mEHT} \text { and } \mathrm{PFS}=1.85 \mathrm{~m} \text { without } \\
\text { mEHT; } \boldsymbol{p}<\mathbf{0 . 0 0 0 1}\end{array}$ & {$[110]$} \\
\hline 20 & Advanced NSCLC & $\begin{array}{l}311(61+197 \\
\quad+53)\end{array}$ & $\begin{array}{l}\text { Radiotherapy }+ \text { chemotherapy }+ \\
\text { mEHT }\end{array}$ & $\begin{array}{l}\text { Two centres PFY }(\boldsymbol{n}=\mathbf{6 1}), \text { HTT }(\boldsymbol{n}=\mathbf{1 9 7}) \\
\text { control }(\boldsymbol{n}=\mathbf{5 3}) .80 \%(\mathrm{PFY}), 80 \%(\mathrm{HTT}) \text { had } \\
\text { distant metastases, conventional therapies } \\
\text { failed. Median OS = 16.4 m (PFY), } 15.6 \mathrm{~m} \\
\text { (HTT), } 14 \mathrm{~m} \text { (control); first-year survival } 67.2 \% \\
\quad \text { (PFY), 64\% (HTT), 26.5\% (control). }\end{array}$ & {$[89,111]$} \\
\hline 21 & Advanced NSCLC & 44 & $\begin{array}{l}\text { Chemotherapy + ketogenic diet }+ \\
\text { hyperbaric oxygen }+ \text { mEHT }\end{array}$ & $\begin{array}{c}\text { Mean OS }=42.9 \mathrm{~m}, \mathrm{PFS}=41 \mathrm{~m} . \text { No problems } \\
\text { were encountered due to fasting, hypoglycemia, } \\
\text { ketogenic diet, mEHT, or hyperbaric oxygen } \\
\text { therapy. }\end{array}$ & {$[112]$} \\
\hline 22 & $\begin{array}{l}\text { Peritoneal } \\
\text { carcinomatosis with } \\
\text { malignant ascites }\end{array}$ & 260 & $\begin{array}{c}\text { mEHT }+ \text { traditional Chinese } \\
\text { medicine }(\mathrm{TCM}) \text { compared to } \\
\text { intraperitoneal chemoinfusion } \\
{[19]}\end{array}$ & $\begin{array}{l}\text { The objective response rate }(\mathrm{OPR})=77.7 \% \text { in } \\
\text { study group (mEHT }+\mathrm{TCM} \text { ) vs. OPR }=63.8 \% \\
\text { in the ICI group. The QoL }=49.2 \% \text { vs. } 32.3 \% \text { in } \\
\text { the active and control group. Adverse effect rate } \\
(\mathrm{AER})=2.3 \% \text { vs. } 12.3 \% .\end{array}$ & [113] \\
\hline 23 & $\begin{array}{l}\text { Advanced rectal } \\
\text { cancer }\end{array}$ & 76 & $\begin{array}{l}\text { mEHT + radiotherapy + } \\
\quad \text { chemotherapy }\end{array}$ & $\begin{array}{l}\text { Downstaging + tumor regression, ypT0, and } \\
\text { ypN0 was better with mEHT than without. No } \\
\text { statistical significance. }\end{array}$ & {$[114]$} \\
\hline 24 & $\begin{array}{l}\text { Liver metastasis } \\
\text { from colorectal } \\
\text { cancer }\end{array}$ & 80 & Chemotherapy + mEHT & $\begin{array}{l}\text { Median OS }=24.5 \mathrm{~m} \text {, and expected (historical) } \\
\qquad \mathrm{OS}=11 \mathrm{~m} \text {. }\end{array}$ & {$[115]$} \\
\hline 25 & $\begin{array}{l}\text { Various types of } \\
\text { sarcoma }\end{array}$ & 13 & $\begin{array}{l}\text { Radiotherapy }+ \text { chemotherapy }+ \\
\text { mEHT }\end{array}$ & $\begin{array}{l}\text { Primary, recurrent, and metastatic sarcomas } \\
\text { responded to mEHT. The masses regressed. }\end{array}$ & {$[116]$} \\
\hline 26 & Soft tissue sarcoma & 24 & Chemotherapy + mEHT & $\begin{array}{c}\text { Pathological response rate }(\mathrm{pRR})=42 \% \text { in } \\
\text { neoadjuvant chemo-hyperthermia treatment } \\
\text { median OS }=31 \mathrm{~m} .\end{array}$ & [117] \\
\hline 27 & $\begin{array}{l}\text { Advanced pancreas } \\
\text { carcinoma }\end{array}$ & 25 & $\begin{array}{l}\text { mEHT }+ \text { chemotherapy }+ \\
\text { ketogenic diet + oxygen therapy }\end{array}$ & $\begin{array}{c}\text { Mean follow-up }=25.4 \mathrm{~m} \text {, median OS }=15.8 \mathrm{~m} \text {, } \\
\text { median PFS }=15.8 \mathrm{~m} .\end{array}$ & {$[118]$} \\
\hline 28 & $\begin{array}{l}\text { Advanced pancreas } \\
\text { carcinoma }\end{array}$ & 26 & Chemotherapy + mEHT & $\mathrm{SD}=9(48 \%), \mathrm{PR}=4(21 \%) \mathrm{PD}=6(31 \%)$ & [119] \\
\hline 29 & Advanced pancreas & 106 & $\begin{array}{l}\text { mEHT + radiotherapy + } \\
\quad \text { chemotherapy }\end{array}$ & $\begin{array}{c}\text { After } 3 \mathrm{~m}, \mathrm{PR}=22(64.7 \%), \mathrm{SD}=10(29.4 \%) \text {, } \\
\mathrm{PD}=2(8.3 \%) \text { with } \mathrm{mEHT} \text { after } 3 \mathrm{~m} \text { of the } \\
\text { therapy. In group without } \mathrm{mEHT} \text { in the same } \\
\text { time: } \mathrm{PR}=3(8.3 \%), \mathrm{SD}=10(27.8 \%), \mathrm{PD}=23 \\
(34.3 \%) . \text { The median } \mathrm{OS}=18 \mathrm{~m} \text { with } \mathrm{mEHT} \\
\text { and } \mathrm{OS}=10.9 \mathrm{~m} \text { without mEHT. }\end{array}$ & {$[101]$} \\
\hline 30 & $\begin{array}{l}\text { Advanced pancreas } \\
\text { carcinoma }\end{array}$ & 20 & $\begin{array}{l}\text { Enzyme-therapy }+ \text { immunolo- } \\
\text { modulation }+ \text { hormone therapy }+ \\
\text { mEHT }\end{array}$ & $\begin{array}{l}\text { Median OS > } 10 \mathrm{~m} \text {. Most patients experienced } \\
\text { partially excellent improvement of QoL. }\end{array}$ & {$[55]$} \\
\hline 31 & $\begin{array}{l}\text { Advanced pancreas } \\
\text { carcinoma }\end{array}$ & $\begin{array}{c}133 \\
(26+73+34)\end{array}$ & $\begin{array}{l}\text { Radiotherapy }+ \text { chemotherapy }+ \\
\text { mEHT }\end{array}$ & $\begin{array}{l}\text { Two centres PFY }(\boldsymbol{n}=\mathbf{2 6}), \text { HTT }(\boldsymbol{n}=\mathbf{7 3}) \text {, } \\
\text { control }(\boldsymbol{n}=\mathbf{3 4}) .59 \% \text { (PFY), } 88 \% \text { (HTT) had } \\
\text { distant metastases, conventional therapies } \\
\text { failed. Median OS = } 12.0 \mathrm{~m} \text { (PFY), } 12.7 \mathrm{~m} \\
\text { (HTT), } 6.5 \mathrm{~m} \text { (control); first-year survival } \\
\text { 46.2\% (PFY), 52.1\% (HTT), 26.5\% (control). } \\
\text { QoL was improved. }\end{array}$ & {$[120]$} \\
\hline
\end{tabular}


TABLE 1: Continued.

\begin{tabular}{|c|c|c|c|c|c|}
\hline No. & Tumor site & $\begin{array}{c}\text { Number of } \\
\text { patients }\end{array}$ & Treatment used & Results & Reference \\
\hline 32 & Ovarian cancer & 19 & mEHT with dose escalation & $\begin{array}{l}\text { The mEHT treatment was feasible in patients } \\
\text { with recurrent or progressive ovarian cancer } \\
\text { without any complications. }\end{array}$ & {$[121]$} \\
\hline 33 & $\begin{array}{l}\text { Metastatic cancers } \\
\text { (colorectal, ovarian, } \\
\text { breast) }\end{array}$ & 23 & $\begin{array}{c}\mathrm{mEHT}+\text { radiotherapy }+ \\
\text { chemotherapy }\end{array}$ & $\begin{array}{c}\text { OS and time to progression (TTP) were } \\
\text { influenced by the number of chemotherapy } \\
\text { cycles }(\boldsymbol{p}<\mathbf{0 . 0 0 1}) \text { and mEHT sessions } \\
(\boldsymbol{p}<\mathbf{0 . 0 0 1}) \text {. Bevacizumab-based chemotherapy } \\
\text { with mEHT had a favourable tumor response, } \\
\text { was feasible and well-tolerated in metastatic } \\
\text { cancer patients. }\end{array}$ & {$[122]$} \\
\hline 34 & $\begin{array}{l}\text { Different types of } \\
\text { metastatic/recurrent } \\
\text { cancers }\end{array}$ & 33 & $\mathrm{mEHT}$ + radiotherapy & $\begin{array}{c}\mathrm{CR}=2(6.1 \%), \text { very good } \mathrm{PR}=5(15.2 \%) \\
\mathrm{PR}=13(39.4 \%), \mathrm{SD}=9(27.3 \%), \mathrm{PD}=4 \\
(12.1 \%) . \text { Three patients }(9.1 \%) \text { developed } \\
\text { autoimmune toxicities. All three patients had } \\
\text { long-lasting abscopal responses outside the } \\
\text { irradiated area. }\end{array}$ & [93] \\
\hline 35 & $\begin{array}{l}\text { Advanced gastric } \\
\text { cancer }\end{array}$ & 24 & $\begin{array}{l}\text { mEHT }+ \text { chemotherapy }+ \\
\text { ketogenic diet }+ \text { oxygen therapy }\end{array}$ & $\begin{array}{c}\mathrm{CR}=22(88 \%) . \text { Mean follow-up }=23.9 \mathrm{~m}, \text { mean } \\
\mathrm{OS}=39.5 \mathrm{~m}, \text { mean PFS }=36.5 \mathrm{~m} .\end{array}$ & [123] \\
\hline
\end{tabular}

as summarised in Table 1. The results of a phase III clinical study [85] showed significant increases in the survival and quality of life [86] of patients with advanced, mostly metastatic uterus cervix tumors. The expected abscopal effect, which was shown in the preclinical phase, was also proven clinically [82]. The resulting immunogenic cell death was a great advantage in treating glioblastoma patients [87]. In particular, complicated malignancies with low expected survival rates (like pancreatic or brain gliomas) have been successfully treated with mEHT (see Table 1). A meta-analysis covering various clinical research groups also demonstrated remarkable results in the treatment of advanced brain gliomas [88]. Importantly, lung malignancies (including both smallcell and nonsmall-cell cancers) can be treated successfully when mEHT is used in combination with conventional treatments (see Table 1). The actual status of mEHT therapy for advanced lung malignancies was reviewed in 2014 [89].

The clinical applications of mEHT fit well with various immuno-oncological therapies, like oncolytic viral treatments [90-92] and checkpoint inhibitors [93]. Clinical studies have continued to investigate the effects of $\mathrm{mEHT}$ in trials to prove its safety and efficacy in complementary combination with different conventional cancer therapies. These studies have been performed independently in various countries, including Hungary, Germany, S. Korea, China, Italy, Canada, and Austria. The results obtained from these studies are promising. Those patients with advanced disease undergoing mEHT have enjoyed significantly elongated survival times and an improved quality of life is proven. Considering the large number of mEHT treatments worldwide, evidencebased clinical studies, together with overall market surveillance, have registered only rare adverse effects: erythema ( $8 \%$ of patients) or minor adipose burns (3\% of patients). In addition, using mEHT like a vaccination could lead to immune modulation and new tumor therapies [92], breaking the therapy resistance to chemotherapy and biological ther- apy [94]. Presently, more clinical trials are ongoing on other types of cancer, including advanced breast, ovarian, and pancreatic lesions.

\section{Conclusion}

The effectiveness of modulated electrohyperthermia as a new hyperthermia method has been shown in numerous studies. Its success derives from nanoscopically heating cancer cells with a high degree of cellular selectivity, which changes the heating paradigm from isothermal homogenous heating to selected cellular heating using the natural heterogeneity of the tumor and its host. In addition, this technique enhances the immune-specific response, which promotes the supporting natural, protective, and defending mechanisms of the human body. [95] Thus, mEHT is a promising therapy that may be used during all phases of cancer treatment in combination with other oncology treatments.

This technique has minimal toxicity and side effects. Clinical studies show that mEHT improves the quality of life and survival rate of patients. Despite the present results, more in vitro experiments and clinical pieces of evidence have to be collected for a broader range of applications and better results. This treatment could give new hope to cancer patients.

\section{Abbreviations}

AA:

AER:

AST:

C26:

CMR:

CR:

DAMP:

DC:
Ascorbic acid

Adverse effect rate

Astrocytoma

Murine colorectal cancer cell line

Complete metabolic response

Complete remission

Damage-associated molecular pattern

Dendritic cell 


$\begin{array}{ll}\text { DFS: } & \text { Disease-free survival } \\ \text { GBM: } & \text { Glioblastoma multiform } \\ \text { GP96: } & \text { Heat shock proteins gp96 } \\ \text { GPR64: } & \text { G-protein-coupled receptor } 64 \\ \text { HMGB1: } & \text { High-mobility group box 1 } \\ \text { Hsp70 and Hsp90: } & \text { Heat shock proteins 70 and 90 } \\ \text { Huh7 and HepG2: } & \text { Hepatocellular carcinoma cell lines } \\ \text { ICD: } & \text { Immunogenic cell death } \\ \text { LDC: } & \text { Local disease control } \\ \text { LDFS: } & \text { Local disease-free survival } \\ \text { mEHT: } & \text { Modulated electrohyperthermia } \\ \text { NED: } & \text { No evidence of disease } \\ \text { NSCLC: } & \text { Nonsmall-cell lung cancer } \\ \text { ORR: } & \text { Objective response rate } \\ \text { OS: } & \text { Overall survival } \\ \text { PD: } & \text { Progressive disease } \\ \text { PFS: } & \text { Progression-free survival } \\ \text { PR: } & \text { Partial remission } \\ \text { pRR: } & \text { Pathological response rate } \\ \text { QoL: } & \text { Quality of life } \\ \text { SCCVII: } & \text { Squamous cell carcinoma cell line } \\ \text { SCLC: } & \text { Small-cell lung cancer } \\ \text { SD: } & \text { Stable disease } \\ \text { SEPT4: } & \text { Septin 4 } \\ \text { TAA: } & \text { Thermo-active agents } \\ \text { TME: } & \text { Tumor microenvironment } \\ \text { TTP: } & \text { Time to progression. }\end{array}$

\section{Data Availability}

The clinical trial and in vitro study data that were used in this review are cited within the article.

\section{Conflicts of Interest}

The authors declare that they have no conflicts of interest.

\section{Acknowledgments}

The authors would like to express their appreciation to Mr. Hani Yamani for his kind help and support, which made this review possible.

\section{References}

[1] WHO, International Agency for research on cancer: Saudi Arabia Source, Globocan 20182018, https:/gco.iarc.fr/today/ data/factsheets/populations/682-saudi-arabia-fact-sheets .pdf.

[2] M. H. Seegenschmiedt and C. C. Vernon, "A historical perspective on hyperthermia in oncology in thermoraiotherapy and thermochemotherapy," in Clinical Applications Vol. 2., Springer, Berlin, Germany, 1995.

[3] S. Roussakow, "The history of hyperthermia rise and decline," Conference Papers in Medicine, vol. 2013, Article ID 428027, 40 pages, 2013.

[4] G. Hegyi, G. Szigeti, and A. Szász, "Hyperthermia versus oncothermia: cellular effects in complementary cancer therapy," Evidence-Based Complementary and Alternative Medicine, vol. 2013, Article ID 672873, 12 pages, 2013.
[5] S. Andras, S. Nora, and S. Oliver, Oncothermia-principles and practices, Springer Science, Heidelberg, 2010.

[6] O. Szasz, "Bioelectromagnetic paradigm of cancer treatment-modulated electro-hyperthermia (mEHT)," Open Journal of Biophysics, vol. 9, no. 2, pp. 98-109, 2019.

[7] J. Kim, B. Prasad, and S. Kim, “Temperature mapping and thermal dose calculation in combined radiation therapy and $13.56 \mathrm{MHz}$ radiofrequency hyperthermia for tumor treatment," in Optical Methods for Tumor Treatment and Detection: Mechanisms and Techniques in Photodynamic Therapy XXVI, D. H. Kessel and T. Hasan, Eds., SPIE, 2017.

[8] B. Prasad, S. Kim, W. Cho, S. Kim, and J. K. Kim, "Effect of tumor properties on energy absorption, temperature mapping, and thermal dose in 13.56- $\mathrm{MHz}$ radiofrequency hyperthermia," Journal of Thermal Biology, vol. 74, pp. 281-289, 2018.

[9] G. Andocs, M. U. Rehman, Q. L. Zhao, Y. Tabuchi, M. Kanamori, and T. Kondo, "Comparison of biological effects of modulated electro-hyperthermia and conventional heat treatment in human lymphoma U937 cells," Cell Death Discovery, vol. 2, no. 1, 2016.

[10] M. G. Vander Heiden, L. C. Cantley, and C. B. Thompson, "Understanding the Warburg effect: the metabolic requirements of cell proliferation," Science, vol. 324, no. 5930, pp. 1029-1033, 2009.

[11] O. Warburg, Dr. Otto Warburg's Cancer Research Papers, 1931, The oxygen transferring ferment of respiration "Nobel Lecture.

[12] R. A. Cardone, V. Casavola, and S. J. Reshkin, "The role of disturbed $\mathrm{pH}$ dynamics and the $\mathrm{Na}+\mathrm{H}+$ exchanger in metastasis," Nature Reviews Cancer, vol. 5, no. 10, pp. 786-795, 2005.

[13] K. O. Alfarouk, A. K. Muddathir, and M. E. Shayoub, “Tumor acidity as evolutionary spite," Cancers, vol. 3 , no. 1, pp. 408414, 2011.

[14] O. Szasz, "Past, present and future of oncothermia," Oncothermia Journal, vol. 9, pp. 55-69, 2013.

[15] G. Szigeti, O. Szász, and G. Hegyi, "Connections between Warburg's and Szentgyorgyi's Approach about the Causes of Cancer," Journal of Neoplasm, vol. 1, no. 2-8, pp. 1-13, 2017.

[16] A. A. Marino, I. G. Iliev, M. A. Schwalke, E. Gonzalez, K. C. Marler, and C. A. Flanagan, "Association between cell membrane potential and breast cancer," Tumour Biology, vol. 15, no. 2, pp. 82-89, 1994.

[17] J. C. Cure, On the electrical charateristics of cancer II. in proceeding of the international congress of electrochemical treatment of cancer, Jupiter, Florida, USA, 1995.

[18] J. C. Cure, Cancer an electrical phenomenon, vol. 11, Resonant, 1991.

[19] E. Revici, Research in physiopathology as basis of guided chemotherapy: with special application to cancer, American Foundation for Cancer Research, Inc, 1961.

[20] T. E. Merchant, P. Meneses, L. W. Gierke, W. den Otter, and T. Glonek, "31P magnetic resonance phospholipid profiles of neoplastic human breast tissues," British Journal of Cancer, vol. 63, no. 5, pp. 693-698, 1991.

[21] A. B. Hendrich and K. Michalak, "Lipids as a target for drugs modulating multidrug resistance of cancer cells," Current Drug Targets, vol. 4, no. 1, pp. 23-30, 2003. 
[22] B. Nordenström, Biologically closed electric circuits: clinical, experimental and theoretical evidence for an additional circulatory system, Nordic Medical Publications, 1983.

[23] B. Nordenström, Exploring BCEC-Systems, Nordic Medical Publ., 1998.

[24] S. Andras, S. Oliver, and S. Nora, "Physical background and technical realization of hyperthermia," in Locoregional radifrequency perfusional and wholebody hyperthermia in cancer treatment Vol. 3, New York Springer., 2006.

[25] A. Szasz, G. Y. Vincze, O. Szasz, and N. Szasz, "An energy analysis of extracellular hyperthermia," Electromagnetic Biology and Medicine, vol. 22, no. 2-3, pp. 103-115, 2009.

[26] G. Andocs, H. Renner, L. Balogh, L. Fonyad, C. Jakab, and A. Szasz, "Strong synergy of heat and modulated electromagnetic field in tumor cell killing," Strahlentherapie und Onkologie, vol. 185, no. 2, pp. 120-126, 2009.

[27] R. Pethig, "Dielectric properties of biological Materials: biophysical and medical Applications," IEEE Transactions on Electrical Insulation, vol. EI-19, no. 5, pp. 453-474, 1984.

[28] F. Barnes and Y. Kwon, "A theoretical study of the effects of RF fields in the vicinity of membranes," Bioelectromagnetics, vol. 26, no. 2, pp. 118-124, 2005.

[29] J. T. Groves, S. G. Boxer, and H. M. McConnell, "Electric field-induced reorganization of two-component supported bilayer membranes," Proceedings of the National Academy of Sciences of the United States of America, vol. 94, no. 25, pp. 13390-13395, 1997.

[30] J. T. Groves, S. G. Boxer, and H. M. McConnell, "Electric field-induced critical demixing in lipid bilayer membranes," Proceedings of the National Academy of Sciences of the United States of America, vol. 95, no. 3, pp. 935-938, 1998.

[31] B. Blad and B. Baldetorp, "Impedance spectra of tumour tissue in comparison with normal tissue; a possible clinical application for electrical impedance tomography," Physiological Measurement, vol. 17, no. 4A, pp. A105-A115, 1996.

[32] B. Blad, P. Wendel, M. Jonsson, and K. Lindstrom, "An electrical impedance index to distinguish between normal and cancerous tissues," Journal of Medical Engineering \& Technology, vol. 23, no. 2, pp. 57-62, 2009.

[33] G. Fiorentini and A. Szasz, "Hyperthermia today: electric energy, a new opportunity in cancer treatment," Journal of Cancer Research and Therapeutics, vol. 2, no. 2, pp. 41-46, 2006.

[34] Y. Zou and Z. Guo, "A review of electrical impedance techniques for breast cancer detection," Medical Engineering \& Physics, vol. 25, no. 2, pp. 79-90, 2003.

[35] D. I. de Pomerai, B. Smith, A. Dawe et al., "Microwave radiation can alter protein conformation without bulk heating," FEBS Letters, vol. 543, no. 1-3, pp. 93-97, 2003.

[36] M. Zhao, J. V. Forrester, and C. D. McCaig, "A small, physiological electric field orients cell division," Proceedings of the National Academy of Sciences of the United States of America, vol. 96, no. 9, pp. 4942-4946, 1999.

[37] E. D. Kirson, Z. Gurvich, R. Schneiderman et al., "Disruption of cancer cell replication by alternating electric fields," Cancer Research, vol. 64, no. 9, pp. 3288-3295, 2004.

[38] A. Szasz, G. Andocs, O. Szasz, G. Vincze, T. Koncz, and L. Balogh, "Effects Far from Equilibrium in Electromagnetic Heating of Tissues," Oncothermia Journal, vol. 1, pp. 41-42, 2010 .
[39] P. Wust, P. Ghadjar, J. Nadobny et al., "Physical analysis of temperature-dependent effects of amplitude-modulated electromagnetic hyperthermia," International Journal of Hyperthermia, vol. 36, no. 1, pp. 1246-1254, 2019.

[40] E. Papp, T. Vancsik, E. Kiss, and O. Szasz, "Energy absorption by the membrane rafts in the modulated electrohyperthermia (mEHT)," Open Journal of Biophysics, vol. 7, no. 4, pp. 216-229, 2017.

[41] G. Gramse, A. Dols-Perez, M. A. Edwards, L. Fumagalli, and G. Gomila, "Nanoscale measurement of the dielectric constant of supported lipid bilayers in aqueous solutions with electrostatic force microscopy," Biophysical Journal, vol. 104, no. 6, pp. 1257-1262, 2013.

[42] S. Dharia, Spatially and temporally resolving radio-frequency changes in effective cell membrane capacitance, The University of Utah, 2011, QP6.5 2011 .D43.

[43] L. J. Pike, "Lipid rafts: bringing order to chaos," Journal of Lipid Research, vol. 44, no. 4, pp. 655-667, 2003.

[44] J. Nickoloff, N. Sharma, and L. Taylor, "Clustered DNA double-strand breaks: biological effects and relevance to cancer radiotherapy," Genes, vol. 11, no. 1, p. 99, 2020.

[45] A. Szasz, "Thermal and nonthermal effects of radiofrequency on living state and applications as an adjuvant with radiation therapy," Journal of Radiation and Cancer Research, vol. 10, no. 1, pp. 1-17, 2019.

[46] G. P. Szigeti, O. Szász, and G. Hegyi, "Personalised Dosing of Hyperthermia," Journal of Cancer Diagnosis, vol. 1, no. 2, 2016.

[47] R. A. M. Canters, M. Franckena, J. van der Zee, and G. C. van Rhoon, "Optimizing deep hyperthermia treatments: are locations of patient pain complaints correlated with modelled SAR peak locations?," Physics in Medicine and Biology, vol. 56, no. 2, pp. 439-451, 2011.

[48] A. Szasz, "Bioelectromagnetic Paradigm of Cancer Treatment: Oncothermia," in Bioelectromagnetic and Subtle Energy Medicine, pp. 323-336, Taylor \& Francis Group, 2014.

[49] A. Szasz, "Oncothermia: complex therapy by EM and fractal physiology," in 2014 XXXIth URSI General Assembly and Scientific Symposium (URSI GASS), Beijing, China, Aug. 2014.

[50] S. Jeelani, R. C. Reddy, T. Maheswaran, G. S. Asokan, A. Dany, and B. Anand, "Theranostics: a treasured tailor for tomorrow," Journal of Pharmacy \& Bioallied Sciences, vol. 6, Suppl 1, pp. S6-S8, 2014.

[51] G. Nagy, N. Meggyeshazi, and O. Szasz, "Deep temperature measurements in oncothermia processes," Conference Papers in Medicine, vol. 2013, Article ID 685264, 6 pages, 2013.

[52] L. Balogh, A. Polyák, Z. Pöstényi, V. Kovács-Haász, M. Gyöngy, and J. Thuróczy, "Temperature increase induced by modulated electrohyperthermia (oncothermia ${ }^{\circledR}$ ) in the anesthetized pig liver," Journal of Cancer Research and Therapeutics, vol. 12, no. 3, pp. 1153-1159, 2016.

[53] Y. W. Tsang, K. H. Chi, C. C. Huang et al., "Modulated electro-hyperthermia-enhanced liposomal drug uptake by cancer cells [Corrigendum]," International Journal of Nanomedicine, vol. Volume 14, pp. 1995-1996, 2019.

[54] B. Prasad, S. Kim, W. Cho et al., "Quantitative estimation of the equivalent radiation dose escalation using radiofrequency hyperthermia in mouse xenograft models of human lung cancer," Scientific Reports, vol. 9, no. 1, p. 3942, 2019.

[55] S. Y. Lee, J. H. Kim, Y. H. Han, and D. H. Cho, "The effect of modulated electro-hyperthermia on temperature and blood 
flow in human cervical carcinoma," International Journal of Hyperthermia, vol. 34, no. 7, pp. 953-960, 2018.

[56] S. Lee and M.-G. Kim, "The effect of modulated electrohyperthermia on the pharmacokinetic properties of nefopam in healthy volunteers: a randomised, single-dose, crossover open-label study," International Journal of Hyperthermia, vol. 31, no. 8, pp. 869-874, 2015.

[57] V. Gy, S. Gy, and A. G, "Nanoheating without artificial nanoparticles," Biology and Medicine, vol. 7, no. 5, 2015.

[58] K.-L. Yang, C. C. Huang, M. S. Chi et al., "In vitrocomparison of conventional hyperthermia and modulated electro-hyperthermia," Oncotarget, vol. 7, no. 51, pp. 84082-84092, 2016.

[59] S. Y. Lee, G. P. Szigeti, and A. M. Szasz, "Oncological hyperthermia: the correct dosing in clinical applications," International Journal of Oncology, vol. 54, no. 2, pp. 627-643, 2019.

[60] G. Andocs, O. Szasz, and A. Szasz, "Oncothermia treatment of cancer: from the laboratory to clinic," Electromagnetic Biology and Medicine, vol. 28, no. 2, pp. 148-165, 2009.

[61] N. Meggyeshazi, G. Andocs, L. Balogh et al., "DNA fragmentation and caspase-independent programmed cell death by modulated electrohyperthermia," Strahlentherapie und Onkologie, vol. 190, no. 9, pp. 815-822, 2014.

[62] G. Andocs, N. Meggyeshazi, L. Balogh et al., "Upregulation of heat shock proteins and the promotion of damage-associated molecular pattern signals in a colorectal cancer model by modulated electrohyperthermia," Cell Stress and Chaperones, vol. 20, no. 1, pp. 37-46, 2015.

[63] Y.-J. Wang, R. Fletcher, J. Yu, and L. Zhang, "Immunogenic effects of chemotherapy-induced tumor cell death," Genes \& Diseases, vol. 5, no. 3, pp. 194-203, 2018.

[64] D. D’Eliseo, L. Manzi, and F. Velotti, "Capsaicin as an inducer of damage-associated molecular patterns (DAMPs) of immunogenic cell death (ICD) in human bladder cancer cells," Cell Stress and Chaperones, vol. 18, no. 6, pp. 801808, 2013.

[65] A. D. Garg, D. Nowis, J. Golab, P. Vandenabeele, D. V. Krysko, and P. Agostinis, "Immunogenic cell death, DAMPs and anticancer therapeutics: an emerging amalgamation," Biochimica et Biophysica Acta, vol. 1805, no. 1, pp. 53-71, 2010.

[66] A. D. Garg, D. V. Krysko, P. Vandenabeele, and P. Agostinis, "Hypericin-based photodynamic therapy induces surface exposure of damage-associated molecular patterns like HSP70 and calreticulin," Cancer Immunology, Immunother$a p y$, vol. 61, no. 2, pp. 215-221, 2012.

[67] A. D. Garg, S. Martin, J. Golab, and P. Agostinis, "Danger signalling during cancer cell death: origins, plasticity and regulation," Cell Death and Differentiation, vol. 21, no. 1, pp. 26-38, 2014.

[68] O. Kepp, L. Galluzzi, I. Martins et al., "Molecular determinants of immunogenic cell death elicited by anticancer chemotherapy," Cancer Metastasis Reviews, vol. 30, no. 1, pp. 61-69, 2011.

[69] P. Sachamitr and P. J. Fairchild, "Cross presentation of antigen by dendritic cells: mechanisms and implications for immunotherapy," Expert Review of Clinical Immunology, vol. 8, no. 6, pp. 547-555, 2014.

[70] W. Qin, Y. Akutsu, G. Andocs et al., "Modulated electrohyperthermia enhances dendritic cell therapy through an abscopal effect in mice," Oncology Reports, vol. 32, no. 6, pp. 2373-2379, 2014.
[71] Y. W. Tsang, C. C. Huang, K. L. Yang et al., "Improving immunological tumor microenvironment using electrohyperthermia followed by dendritic cell immunotherapy," BMC Cancer, vol. 15, no. 1, 2015.

[72] S. C. Formenti and S. Demaria, "Systemic effects of local radiotherapy," The Lancet Oncology, vol. 10, no. 7, pp. 718726, 2009.

[73] J. Banchereau and R. M. Steinman, "Dendritic cells and the control of immunity," Nature, vol. 392, no. 6673, pp. 245252, 1998.

[74] K. H. Chi, S. J. Liu, C. P. Li et al., "Combination of conformal radiotherapy and intratumoral injection of adoptive dendritic cell immunotherapy in refractory hepatoma," Journal of Immunotherapy, vol. 28, no. 2, pp. 129-135, 2005.

[75] G. A. Rabinovich, D. Gabrilovich, and E. M. Sotomayor, "Immunosuppressive strategies that are mediated by tumor cells," Annual Review of Immunology, vol. 25, no. 1, pp. 267-296, 2007.

[76] T. Goto, T. Nishi, T. Tamura et al., "Highly efficient electrogene therapy of solid tumor by using an expression plasmid for the herpes simplex virus thymidine kinase gene," Proceedings of the National Academy of Sciences of the United States of America, vol. 97, no. 1, pp. 354-359, 2000.

[77] C. H. Chi, Y. S. Wang, Y. S. Lai, and K. H. Chi, “Anti-tumor effect of in vivo IL-2 and GM-CSF electrogene therapy in murine hepatoma model," Anticancer Research, vol. 23, no. 1a, pp. 315-321, 2003.

[78] K. H. Chi, Y. S. Wang, and S. J. Kao, "Improving radioresponse through modification of the tumor immunological microenvironment," Cancer Biotherapy \& Radiopharmaceuticals, vol. 27, no. 1, pp. 6-11, 2012.

[79] Y. S. Wang, S. J. Liu, S. C. Huang et al., "Recombinant heat shock protein 70 in combination with radiotherapy as a source of tumor antigens to improve dendritic cell immunotherapy," Frontiers in Oncology, vol. 2, 2012.

[80] Y. S. Wang, Y. W. Tsang, C. H. Chi, C. C. Chang, R. M. Chu, and K. H. Chi, "Synergistic anti-tumor effect of combination radio- and immunotherapy by electro-gene therapy plus intra-tumor injection of dendritic cells," Cancer Letters, vol. 266, no. 2, pp. 275-285, 2008.

[81] T. Vancsik, C. Kovago, E. Kiss et al., "Modulated electrohyperthermia induced loco-regional and systemic tumor destruction in colorectal cancer allografts," Journal of Cancer, vol. 9, no. 1, pp. 41-53, 2018.

[82] C. Minnaar, J. A. Kotzen, O. A. Ayeni, M. D. T. Vangu, and A. Baeyens, "Potentiation of the abscopal effect by modulated electro-hyperthermia in locally advanced cervical cancer patients," Frontiers in Oncology, vol. 10, 2020.

[83] T. W. Jeon, H. Yang, C. G. Lee et al., "Electro-hyperthermia up-regulates tumour suppressor Septin 4 to induce apoptotic cell death in hepatocellular carcinoma," International Journal of Hyperthermia, vol. 32, no. 6, pp. 648-656, 2016.

[84] A. M. Szasz, C. A. Minnaar, G. Szentmártoni, G. P. Szigeti, and M. Dank, "Review of the clinical evidences of modulated electro-hyperthermia (mEHT) method: an update for the practicing oncologist," Frontiers in Oncology, vol. 9, 2019.

[85] C. A. Minnaar, J. A. Kotzen, O. A. Ayeni et al., "The effect of modulated electro-hyperthermia on local disease control in HIV-positive and -negative cervical cancer women in South Africa: early results from a phase III randomised controlled trial," PLoS One, vol. 14, no. 6, article e0217894, 2019. 
[86] C. Minnaar, J. A. Kotzen, T. Naidoo et al., "Analysis of the effects of mEHT on the treatment- related toxicity and quality of life of HIV-positive cervical cancer patients," International Journal of Hyperthermia, vol. 37, no. 1, pp. 263-272, 2020.

[87] S. VanGool, "The induction of immunogenic cell death ( ICD ) during maintenance chemotherapy and subsequent multimodal immunotherapy for glioblastoma ( GBM )," Austin Oncology Case Reports, vol. 3, no. 1, pp. 1-8, 2018.

[88] S. V. Roussakow, "Clinical and economic evaluation of modulated electrohyperthermia concurrent to dose-dense temozolomide 21/28 days regimen in the treatment of recurrent glioblastoma: a retrospective analysis of a two-centre German cohort trial with systematic comparison and effect-totreatment analysis," BMJ Open, vol. 7, no. 11, article e017387, 2017.

[89] A. Szasz, "Current status of oncothermia therapy for lung cancer," The Korean Journal of Thoracic and Cardiovascular Surgery, vol. 47, no. 2, pp. 77-93, 2014.

[90] V. Schirrmacher, A. S. Bihari, W. Stücker, and T. Sprenger, "Long-term remission of prostate cancer with extensive bone metastases upon immuno- and virotherapy: a case report," Oncology Letters, vol. 8, no. 6, pp. 2403-2406, 2014.

[91] V. Schirrmacher, W. Stücker, M. Lulei, A. S. Bihari, and T. Sprenger, "Long-term survival of a breast cancer patient with extensive liver metastases upon immune and virotherapy: a case report," Immunotherapy, vol. 7, no. 8, pp. 855860, 2015.

[92] S. Volker, "A New Strategy of Cancer Immunotherapy Combining Hyperthermia/Oncolytic Virus Pretreatment with Specific Autologous Anti-Tumor Vaccination - A Review," Austin Oncology Case Reports, vol. 2, no. 1, 2017.

[93] M.-S. Chi, M. P. Mehta, K. L. Yang et al., "Putative abscopal effect in three patients treated by combined radiotherapy and modulated electrohyperthermia," Frontiers in Oncology, vol. 10, p. 254, 2020.

[94] V. Schirrmacher, S. van Gool, and W. Stuecker, "Breaking therapy resistance: an update on oncolytic newcastle disease virus for improvements of cancer therapy," Biomedicine, vol. 7, no. 3, p. 66, 2019.

[95] S. J. W. Kim and A. Szasz, "History of hyperthermia and electro-medicine. (abstract of poster)," Oncothermia Journal, vol. 1, pp. 44-44, 2010.

[96] C. Wismeth, C. Dudel, C. Pascher et al., "Transcranial electro-hyperthermia combined with alkylating chemotherapy in patients with relapsed high-grade gliomas: phase I clinical results," Journal of Neuro-Oncology, vol. 98, no. 3, pp. 395-405, 2010.

[97] G. Fiorentini, P. Giovanis, S. Rossi et al., "A phase II clinical study on relapsed malignant gliomas treated with electrohyperthermia," In Vivo, vol. 20, no. 6a, pp. 721-724, 2006.

[98] G. Fiorentini et al., "Retrospective observational clinical study on relapsed malignant gliomas treated with electro-hyperthermia," Oncothermia Journal, vol. 45, pp. 22-32, 2018.

[99] H. Sahinbas, D. Grönemeyer, E. Böcher, and A. Szasz, "Retrospective clinical study of adjuvant electro-hyperthermia treatment for advanced brain-gliomas," Deutsche Zeitschrift für Onkologie, vol. 39, no. 4, pp. 154-160, 2007.

[100] E. D. Hager, H. Sahinbas, D. H. Groenemeyer, and F. Migeod, "Prospective phase II trial for recurrent high-grade gliomas with capacitive coupled low radiofrequency (LRF) hyperther- mia," Journal of Clinical Oncology, vol. 26, 15_suppl, p. 2047, 2008.

[101] G. Fiorentini, D. Sarti, C. Milandri et al., "Modulated electrohyperthermia in integrative cancer treatment for relapsed malignant glioblastoma and astrocytoma: retrospective multicenter controlled study," Integrative Cancer Therapies, vol. 18, article 1534735418812691, 2019.

[102] G. Gadaleta-Caldarola, S. Infusino, I. Galise et al., "Sorafenib and locoregional deep electro-hyperthermia in advanced hepatocellular carcinoma: a phase II study," Oncology Letters, vol. 8, no. 4, pp. 1783-1787, 2014.

[103] V. Ferrari, S. de Ponti, F. Valcamonico et al., "Deep electrohyperthermia (EHY) with or without thermo-active agents in patients with advanced hepatic cell carcinoma: phase II study," Journal of Clinical Oncology, vol. 25, 18_suppl, pp. 15168-15168, 2007.

[104] D. Y. Lee, S. J. Haam, T. H. Kim, J. Y. Lim, E. J. Kim, and N. Y. Kim, "Oncothermia with chemotherapy in the patients with small-cell lung cancer," Conference Papers in Medicine, vol. 2013, Article ID 910363, 7 pages, 2013.

[105] C. Minnaar, A. Baeyens, and J. Kotzen, “O34. Update on phase III randomized clinical trial investigating the effects of the addition of electro-hyperthermia to chemoradiotherapy for cervical cancer patients in South Africa," Physica Medica, vol. 32, pp. 151-152, 2016.

[106] S. Y. Lee, N. R. Lee, D. H. Cho, and J. S. Kim, “Treatment outcome analysis of chemotherapy combined with modulated electro-hyperthermia compared with chemotherapy alone for recurrent cervical cancer, following irradiation," Oncology Letters, vol. 14, no. 1, pp. 73-78, 2017.

[107] L. Pesti, Z. Dankovics, P. Lorencz, and A. Csejtei, “Treatment of advanced cervical cancer with complex chemoradiohyperthermia," Conference Papers in Medicine, vol. 2013, Article ID 192435, 4 pages, 2013.

[108] E. D. Hager, B. Süsse, C. Popa, G. Schritttwieser, A. Heise, and R. Kleef, "Complex therapy of the not in sano respectable carcinoma of the pancreas - a pilot study," Journal of Cancer Research and Clinical Oncology, vol. 120, 1994.

[109] J. Ou, X. Zhu, Y. Lu et al., "The safety and pharmacokinetics of high dose intravenous ascorbic acid synergy with modulated electrohyperthermia in Chinese patients with stage IIIIV non-small cell lung cancer," European Journal of Pharmaceutical Sciences, vol. 109, pp. 412-418, 2017.

[110] J. Ou, X. Zhu, P. Chen et al., "A randomized phase II trial of best supportive care with or without hyperthermia and vitamin $\mathrm{C}$ for heavily pretreated, advanced, refractory nonsmall-cell lung cancer," Journal of Advanced Research, vol. 24, pp. 175-182, 2020.

[111] A. Dani, A. Varkonyi, T. Magyar, and A. Szasz, "Clinical study for advanced non-small-cell lung cancer treated by oncothermia," Oncothermia Journal, vol. 3, pp. 40-49, 2011.

[112] M. S. Iyikesici, "Feasibility study of metabolically supported chemotherapy with weekly carboplatin/paclitaxel combined with ketogenic diet, hyperthermia and hyperbaric oxygen therapy in metastatic non-small cell lung cancer," International Journal of Hyperthermia, vol. 36, no. 1, pp. 446-455, 2019.

[113] C. L. K. Pang, X. Zhang, Z. Wang et al., "Local modulated electro-hyperthermia in combination with traditional Chinese medicine vs. intraperitoneal chemoinfusion for the treatment of peritoneal carcinomatosis with malignant 
ascites: a phase II randomized trial," Molecular and Clinical Oncology, vol. 6, no. 5, pp. 723-732, 2017.

[114] S. H. You and S. Kim, "Feasibility of modulated electrohyperthermia in preoperative treatment for locally advanced rectal cancer: early phase 2 clinical results," Neoplasma, vol. 67 , no. 3, pp. 677-683, 2020.

[115] E. D. Hager, H. Dziambor, D. Höhmann, D. Gallenbeck, M. Stephan, and C. Popa, "Deep hyperthermia with radiofrequencies in patients with liver metastases from colorectal cancer," Anticancer Research, vol. 19, no. 4c, pp. 3403-3408, 1999.

[116] T. Jeung, S. Y. Ma, J. H. Choi, J. Yu, S. Y. Lee, and S. Lim, "Results of oncothermia combined with operation, chemotherapy and radiation therapy for primary, recurrent and metastatic sarcoma," Case Reports in Clinical Medicine, vol. 4, no. 5, pp. 157-168, 2015.

[117] S. R. Volovat, C. Volovat, V. Scripcariu, C. Lupascu, and L. Miron, "The results of combination of ifosfamid and locoregional hyperthermia (EHY 2000) in patients with advanced abdominal soft-tissue sarcoma after relapse of first line chemotherapy," Romanian Reports in Physics, vol. 66, pp. 175$181,2014$.

[118] M. S. Iyikesici, "Long-term survival outcomes of metabolically supported chemotherapy with gemcitabine-based or FOLFIRINOX regimen combined with ketogenic diet, hyperthermia, and hyperbaric oxygen therapy in metastatic pancreatic cancer," Complementary Medicine Research, vol. 27, no. 1, pp. 31-39, 2020.

[119] C. Volovat, S. R. Volovat, V. Scripcaru, and L. Miron, "Second-line chemotherapy with gemcitabine and oxaliplatin in combination with loco-regional hyperthermia (EHY-2000) in patients with refractory metastatic pancreatic cancerpreliminary results of a prospective trial," Romanian Reports in Physics, vol. 66, pp. 166-174, 2013.

[120] A. Dani, A. Varkonyi, T. Magyar, M. Kalden, and A. Szasz, "Clinical study for advanced pancreas cancer treated by oncothermia. Forum Hyperthermie, 1:13-20," Oncothermia Journal, vol. 6, pp. 11-25, 2012.

[121] H. J. Yoo, M. C. Lim, S. S. Seo, S. Kang, J. Joo, and S. Y. Park, "Phase I/II clinical trial of modulated electro-hyperthermia treatment in patients with relapsed, refractory or progressive heavily treated ovarian cancer," Japanese Journal of Clinical Oncology, vol. 49, no. 9, pp. 832-838, 2019.

[122] G. Ranieri, C. Ferrari, A. D. Palo et al., "Bevacizumab-based chemotherapy combined with regional deep capacitive hyperthermia in metastatic cancer patients: a pilot study," International Journal of Molecular Sciences, vol. 18, no. 7, p. 1458, 2017.

[123] M. Iyikesici, "Survival outcomes of metabolically supported chemotherapy combined with ketogenic diet, hyperthermia, and hyperbaric oxygen therapy in advanced gastric cancer," Nigerian Journal of Clinical Practice, vol. 23, no. 5, pp. 734$740,2020$.

[124] J. Zhou, G. Wang, Y. Chen, H. Wang, Y. Hua, and Z. Cai, "Immunogenic cell death in cancer therapy: present and emerging inducers," Journal of Cellular and Molecular Medicine, vol. 23, no. 8, pp. 4854-4865, 2019. 